\title{
Plasma leptin concentrations and esophageal hypomotility in obese patients
}

\author{
Justin Côté-Daigneault MD¹, Pierre Poitras MD¹, Rémi Rabasa-Lhoret MD PhD²,3, Mickael Bouin MD PhD
}

J Côté-Daigneault, P Poitras, R Rabasa-Lhoret, M Bouin. Plasma leptin concentrations and esophageal hypomotility in obese patients. Can J Gastroenterol Hepatol 2015;29(1):49-51.

BACKGROUND: Although esophageal hypomotility is prevalent in obese patients, its cause remains unknown. Leptin, a hormone derived from adipose tissue, may be involved in this phenomenon because it has been shown to decrease gastric and intestinal motility in animals. It has been hypothesized that elevated plasma leptin concentration is a risk factor for esophageal dysmotility in obese patients.

OBJECTIVE: To determine whether plasma leptin concentrations are higher in obese patients with esophageal hypomotility than in obese patients with a normal motility profile.

METHOD: Fasting plasma leptin concentration (assessed by radioimmuoassay) was measured in all patients who were included in a study protocol investigating esophageal manometry before bariatric surgery. The patients completed standardized surveys regarding epidemiological data, upper gastrointestinal symptoms, medical history and medication(s). Basal levels of leptin, as well as corrected leptin scores adjusted for sex and body mass index, were compared in patients with and without esophageal dysmotility.

RESULTS: Nine patients without dysmotility and eight with dysmotility were included. Both groups were comparable with regard to age ( $42 \pm 9$ versus $38 \pm 9$ years), sex ( $78 \%$ versus $75 \%$ women) and body mass index $\left(49 \pm 10 \mathrm{~kg} / \mathrm{m}^{2}\right.$ versus $\left.42 \pm 7 \mathrm{~kg} / \mathrm{m}^{2}\right)$. There were no significant differences regarding medication(s) and comorbidities between the two groups. When compared with normal predicted values, the corrected leptin scores were $30 \%$ higher in patients with dysmotility than in the control group with normal motility $(\mathrm{P} \leq 0.05)$.

CONCLUSION: Obese patients with esophageal dysmotility exhibited elevated plasma leptin concentrations, suggesting a role for leptin in promoting esophageal hypomotility.

Key Words: Bariatric surgery; Digestive motility disorders; Esophageal motility; Leptin; Manometry; Obesity

Obesit besity is asociated with several metabolic, cardiovascular, respiratory and locomotor disorders (1). Regarding the digestive system, obesity is recognized as a risk factor for cholelithiasis, nonalcoholic steatohepatitis, colorectal cancer and gastroesophageal reflux disease.

Esophageal motor disorders were documented in more than one-half of obese subjects evaluated in a previous report by our group (2), as well as in other reports in the literature $(3,4)$, in which esophageal body hypomotility was the most prevalent abnormality, regardless of upper gastrointestinal symptoms, comorbidities or medications. The cause of this phenomenon remains unknown. An association between leptin and gastrointestinal motility disorders may explain this phenomenon.

Leptin, a hormone largely derived from adipose tissue, increases satiety and modulates energy balance (5). Basal leptin concentrations vary according to sex, weight and the time of day (6). Elevated leptin levels have been demonstrated in the obese population (7). It is known

\section{Les concentrations plasmatiques de leptine et l'hypomobilité œesophagienne chez les patients obèses}

HISTORIQUE : On ne connaît pas la cause de l'hypomotilité œesophagienne, malgré sa prévalence chez les patients obèses. La leptine, une hormone dérivée des tissus adipeux, pourrait contribuer à ce phénomène, car elle réduit la motilité gastrique et intestinale chez les animaux. Il est postulé qu'une concentration plasmatique élevée de leptine est un facteur de risque de dysmotilité œsophagienne chez les patients obèses. OBJECTIF: Déterminer si les concentrations plasmatiques de leptine sont plus élevées chez les patients obèses présentant une hypomotilité œsophagienne que chez les patients obèses dont le profil de motilité est normal.

MÉTHODOLOGIE : Les chercheurs ont mesuré les concentrations plasmatiques de leptine à jeun (évaluées par dosage radio-immunologique) chez tous les patients qui ont participé à un protocole d'étude sur la manométrie œsophagienne avant une chirurgie bariatrique. Les patients ont rempli des sondages standardisés sur leurs données épidémiologiques, leurs symptômes des voies digestives supérieures, leurs antécédents médicaux et leur médication. Les taux de leptine de base, de même que les scores de leptine corrigés en fonction du sexe et l'indice de masse corporelle, ont été comparés entre les patients ayant une dysmotilité œsophagienne ou non.

RÉSULTATS : Neuf patients ne présentant pas de dysmotilité et huit en présentant une ont fait partie de l'étude. Les deux groupes étaient comparables sur le plan de l'âge $(42 \pm 9$ et $38 \pm 9$ ans), du sexe ( $78 \%$ et $75 \%$ de femmes) et de l'indice de masse corporelle $\left(49 \pm 10 \mathrm{~kg} / \mathrm{m}^{2}\right.$ et $\left.42 \pm 7 \mathrm{~kg} / \mathrm{m}^{2}\right)$. Ils ne présentaient pas de différences significatives quant à la prise de médicaments et aux comorbidités. Par rapport aux valeurs prévues normales, les scores de leptine corrigés étaient $30 \%$ plus élevés chez les patients présentant une dysmotilité que dans le groupe témoin dont la motilité était normale $(\mathrm{P} \leq 0,05)$.

CONCLUSION : Les patients obèses ayant une dysmotilité œesophagienne présentaient des concentrations plasmatiques élevées de leptine, ce qui laisse croire que la leptine contribue à promouvoir l'hypomotilité œsophagienne.

that leptin receptors at the blood-brain barrier are saturated and that the response of hypothalamic cells to leptin is decreased in obese patients. As a result, leptin in these patients cannot regulate satiety and modulate energy balance.

In animal studies, leptin decreased gastric emptying and small intestinal motility (8-10). Leptin receptors located at the afferent and efferent vagus nerve endings are a possible explanation. A positive feedback has been proposed between leptin and the hormone cholecystokinin, which is known to inhibit pyloric relaxation and decrease gastric emptying (11). Jorge et al (12) reported that high levels of leptin were related to an increase in wave amplitude in the middle and distal esophagus in diabetic patients.

In the present study, we tested the hypothesis that obese patients with esophageal dysmotilities have higher serum leptin concentrations than obese patients with a normal motility profile.

\footnotetext{
${ }^{1}$ Department of Gastroenterology and ${ }^{2}$ Endocrinology, Centre Hospitalier de l'Université de Montréal (CHUM); ${ }^{3}$ Institut de Recherches Cliniques de Montréal (IRCM), Montreal, Quebec

Correspondence: Dr Mickael Bouin, Gastroenterology Department, CHUM, St-Luc, 1058 St-Denis, Montreal, Quebec H2X 3J4.

Telephone 514-890-8000, e-mail mickael.bouin@umontreal.ca

Received for publication July 18, 2014. Accepted November 7, 2014
} 
TABLE 1

\section{Patient characteristics}

\begin{tabular}{|c|c|c|c|}
\hline & \multicolumn{2}{|c|}{ Esophageal dysmotility } & \multirow[b]{2}{*}{$\mathbf{P}$} \\
\hline & No $(n=9)$ & Yes $(n=8)$ & \\
\hline \multicolumn{4}{|l|}{ Demographic data } \\
\hline Age, years, mean \pm SD & $42 \pm 10$ & $38 \pm 10$ & NS \\
\hline Female sex & $7(78)$ & $6(75)$ & NS \\
\hline Body mass index, $\mathrm{kg} / \mathrm{m}^{2}$, mean $\pm \mathrm{SD}$ & $49 \pm 10$ & $42 \pm 7$ & NS \\
\hline \multicolumn{4}{|l|}{ Medications } \\
\hline Metoclopramide & $0(0)$ & $0(0)$ & - \\
\hline Domperidone & $0(0)$ & $0(0)$ & - \\
\hline Erythromycin & $0(0)$ & $0(0)$ & - \\
\hline Cisapride & $0(0)$ & $0(0)$ & - \\
\hline Proton pump inhibitor & $2(22)$ & $4(50)$ & NS \\
\hline Anti- $\mathrm{H}_{2}$ & $1(11)$ & $0(0)$ & NS \\
\hline Anticholinergic & $0(0)$ & $0(0)$ & - \\
\hline Opioid & $0(0)$ & $1(13)$ & NS \\
\hline Sildenafil & $0(0)$ & $0(0)$ & - \\
\hline \multicolumn{4}{|l|}{ Comorbidities } \\
\hline Diabetes & $1(11)$ & $1(13)$ & NS \\
\hline Hypothyroidism & $2(22)$ & $2(25)$ & NS \\
\hline Hyperthyroidism & $0(0)$ & $0(0)$ & - \\
\hline Scleroderma & $0(0)$ & $0(0)$ & - \\
\hline Polymyositis & $0(0)$ & $0(0)$ & - \\
\hline Bariatric surgery & $1(11)$ & $1(13)$ & NS \\
\hline Hiatus hernia & $1(11)$ & $0(0)$ & NS \\
\hline Gastroesophageal reflux disease & $3(33)$ & $4(50)$ & NS \\
\hline
\end{tabular}

Data presented as $n(\%)$ unless otherwise indicated. NS Not statisitcally significant

\section{METHODS}

The present analysis was a prospective study conducted at the University of Montreal Hospital Centre (Montreal, Quebec), from September 2011 to December 2012. The present study adhered to the Helsinki declaration and was approved by the Ethics Committee of University of Montreal Hospital Centre.

\section{Patients}

All patients undergoing preoperative evaluation for bariatric surgery were referred for inclusion in a study protocol investigating preoperative esophageal motility. The inclusion criteria were: body mass index $(\mathrm{BMI}) \geq 30 \mathrm{~kg} / \mathrm{m}^{2}$; between 18 and 70 years of age; and without risk for pregnancy. Exclusion criteria were inability to provide free and informed consent, or refusal to participate.

\section{Esophageal manometry}

High-resolution manometry (InSIGHT g3, Sandhill Scientific, USA) was performed by a single technician and the results interpreted by one gastroenterologist specialized in digestive motility disorders. Esophageal manometry was performed according to a standardized protocol.

Manometric measurements were made after 10 swallows of $5 \mathrm{~mL}$ of saline water while supine. The following measurements were recorded: upper esophageal sphincter - upper esophageal sphincter pressure $(\mathrm{mmHg})$ and coordination of sphincter $(\%)$; esophageal body - presence of effective contractions (\%), peristaltic waves (\%), duration of contractions(s), proximal and distal wave of contraction's amplitude $(\mathrm{mmHg})$ and type of contraction waves (primary, secondary or tertiary); and lower esophageal sphincter (LES) - location of the sphincter $(\mathrm{cm})$, LES pressure $(\mathrm{mmHg})$, residual pressure of the LES $(\mathrm{mmHg})$ and relaxation percentage (\%). Normal values corresponded with recognized international standards (13).

\section{Questionnaires}

Two standardized questionnaires were administered to patients after manometry was performed. Data regarding upper gastrointestinal symptoms, epidemiology, comorbidities and medication were

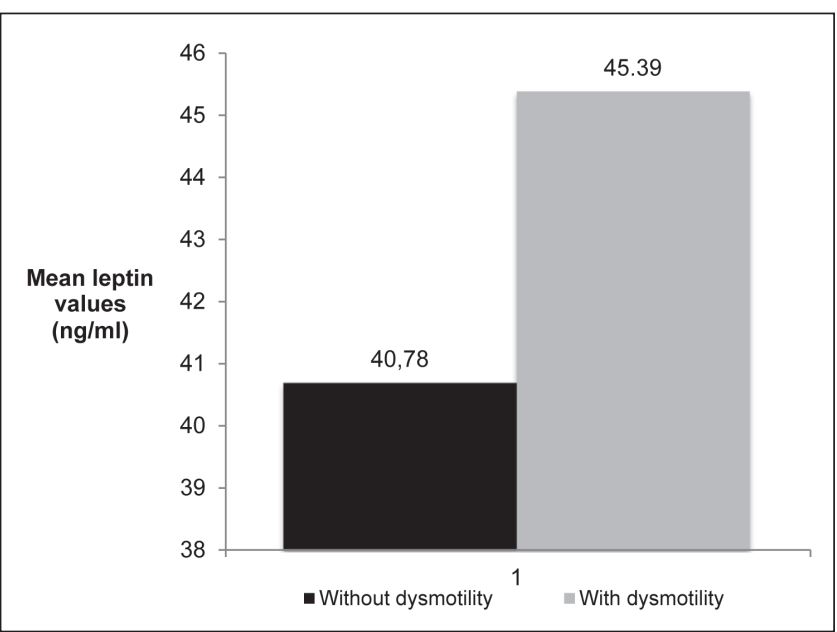

Figure 1) Basal plasma leptin values in obese patients with and without esophageal dysmotility. P Not significant

collected. A review of the medical record was performed to complete the research data.

\section{Leptin}

The measurement of plasma leptin levels was performed using a standardized protocol. The patient fasted $\geq 8 \mathrm{~h}$ before esophageal manometry and a blood sample was drawn. Blood samples were centrifuged and stored at $-80^{\circ} \mathrm{C}$. Plasma leptin levels were measured using radioimmunoassay (Human Leptin RIA kit, Millipore, USA).

Fasting plasma levels of leptin are variable in the general population, with sex and BMI the most recognized factors for this variation. The normal distribution of basal plasma leptin is usually obtained according to the following formulas (6):

$$
\begin{gathered}
\text { Women: } 2.53 \times(\mathrm{BMI})-45.2 \\
\text { Men: } 0.97 \times(\mathrm{BMI})-18.3
\end{gathered}
$$

To take into account these variables and eliminate possible anthropomorphic bias (ie, sex and BMI), a corrected leptin score for each patient was obtained as a ratio of the raw leptin value for the patient divided by the normal predicted value according to sex and BMI.

Using the Wilcoxon test, plasma leptin levels and leptin corrected scores in patient groups with esophageal dysmotility were compared with patients with a normal motility profile.

\section{RESULTS}

Seventeen patients (13 female) were included. The mean $( \pm$ SD) age was $40 \pm 10$ years and the mean BMI was $46 \pm 7 \mathrm{~kg} / \mathrm{m}^{2}$. Esophageal manometry detected dysmotility in $47 \%(n=8)$ of the patients; esophageal body hypomotility was found in $63 \%(n=5)$ of these patients. Following these results, groups with and without esophageal dysmotility were compared. Epidemiological data, medication(s) and comorbidities showed no statistically significant differences (Table 1).

Mean basal leptin levels were higher in the group with dysmotility $(45.39 \mathrm{ng} / \mathrm{mL})$ than in the group without dysmotility $(40.78 \mathrm{ng} / \mathrm{mL})$ (Figure 1) but failed to reach statistical significance $(\mathrm{P}=0.88)$.

Corrected leptin scores, taking into account the known factors of plasma leptin variations, were higher in the group with esophageal dysmotility than in the group without dysmotility (99\% versus $66 \%$ of the predicted value $[\mathrm{P} \leq 0.05]$ ) (Figure 2 ).

\section{DISCUSSION}

Leptin concentrations were higher in obese patients with esophageal dysmotility than in those without esophageal dysmotility. This is in agreement with our starting hypothesis and supports a possible role for leptin in the etiology of esophageal hypomotility in obese patients. 


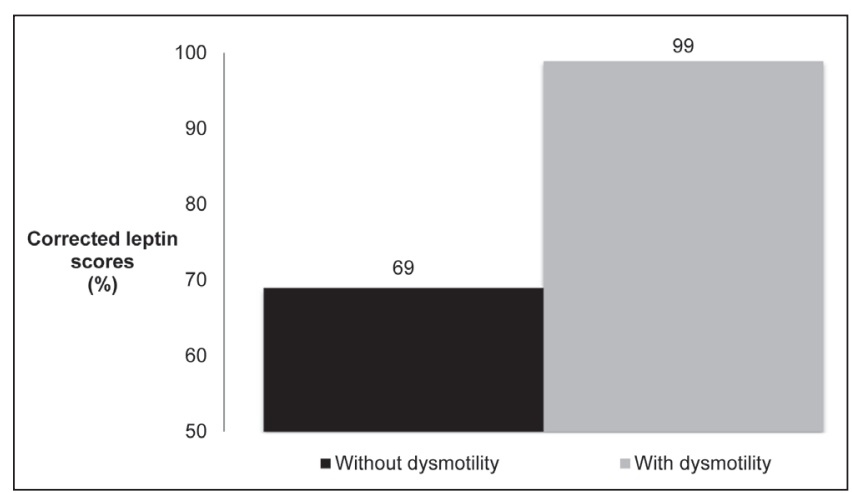

Figure 2) Corrected leptin scores (raw value/predicted value) in obese patients with and without esophageal dysmotility. $P \leq 0.05$

Raw leptin values were higher in the eosophageal dysmotility group but were not statistically significant. This statistical result is not surprising given that plasma leptin levels vary according to sex and BMI. However, the corrected leptin scores (raw leptin value/predicted leptin value), which eliminate potential biases, revealed a clear statistical increase in plasma leptin in obese patients with esophageal dysmotility.

Two patients had previously undergone bariatric surgery. Because leptin is derived from adipose tissue and not gastric mucosa, we do not believe that leptin values in obese patients, even if they have undergone previous bariatric surgery, would be altered.

Esophageal dysmotility was reported in approximately 50\% of obese patients in our previous study (2). The majority (85\%) of these patients had esophageal body hypomotility. In the current study, we

\section{REFERENCES}

1. Prospective Studies Collaboration, Whitlock G, Lewington S, Sherliker P, et al. Body-mass index and cause-specific mortality in 900000 adults: Collaborative analyses of 57 prospective studies. Lancet 2009;373:1083-96.

2. Côté-Daigneault J, Leclerc P, Joubert J, Bouin M. High prevalence of esophageal dysmotility in asymptomatic obese patients. Can J Gastroenterol Hepatol 2014;28:311-4.

3. Jaffin BW, Knoepflmacher P, Greenstein R. High prevalence of asymptomatic motility disorders among morbidly obese patients. Obes Surg 1999:390-5.

4. Koppman JS, Poggi L, Szomstein S, et al. Esophageal motility disorders in the morbidly obese population. Surgical Endosc 2007;21:761-4.

5. Yarandi SS, Hebbar G, Sauer CG, Cole CR, Ziegler TR. Diverse roles of leptin in the gastrointestinal tract: Modulation of motility, absorption, growth, and inflammation. Nutrition 2011;27:269-75.

6. Ma Z, Gingerich RL, Santiago JV, Klein S, Smith CH, Landt M. Radioimmunoassay of leptin in human plasma. Clin Chem 1996;42:942-6. found a similar prevalence of esophageal dysmotility (47\%) and the majority had esophageal body hypomotility. The clinical relevance of these motor disturbances was discussed in our previous report (2).

The rationale linking increased plasma leptin levels with decreased esophageal motility is based on the fact that endogenous leptin is now known to be increased in the plasma of obese patients with esophageal dysmotility, and that exogenous leptin administration decreased gastrointestinal motility in animal models testing this hypothesis (10). We believe that leptin may belong to a digestive physiology feedback in the context of esophageal motility. We know that leptin is produced by adipose tissue in a linear fashion, and that leptin receptors are located at the afferent and efferent vagus nerve endings. Thus, an increase in leptin level could lead to earlier satiety and esophageal dysmotility to modulate energy balance. We are not aware of any studies investigating the biological effect of leptin on esophageal or digestive motility in human subjects. Further research is needed to confirm the contribution of leptin to esophageal dysmotility in obese patients.

\section{CONCLUSION}

Esophageal hypomotility is prevalent in obese patients; however, its cause remains unknown. Leptin has been shown to decrease gastric emptying and intestinal motility in animal models. The present study showed higher leptin concentrations in obese patients with esophageal dysmotility than in those without esophageal dysmotility. Results of the present study support a possible role for leptin in the etiology of esophageal hypomotility in obese patients.

DISCLOSURES: The authors have no financial disclosures or conflicts of interest to declare.

7. Saad MF, Riad-Gabriel MG, Khan A, et al. Diurnal and ultradian rhythmicity of plasma leptin: Effects of gender and adiposity. J Clin Endocrinol Metab 1998;83:453.

8. Çakir B, Kasimay Ö, Devseren E, et al. Leptin inhibits gastric emptying in rats: Role of CCK receptors and vagal afferent fibers. Physiol Res 2007;56:315-22.

9. Kiely JM, Noh JH, Graewin JS, et al. Altered intestinal motility in leptin-deficient obese mice. J Surg Res 2005:124;98-103.

10. Martinez V, Barrachina MD, Wang L, et al. Intracerebroventricular leptin inhibits gastric emptying of a solid nutrient meal in rats. Neuroreport 1999;10:3217.

11. Hata N, Murata S, Maeda J, et al. Predictors of gastric myoelectrical activity in type 2 diabetes mellitus. J Clin Gastroenterol 2009;43:429-36.

12. Jorge JX, Borges CI, Delgado FJ, et al. High levels of leptin modulate esophageal motor characteristics in type 2 diabetic patients. Rom J Intern Med 2011;49:267-71.

13. Pandolfino JE, Kahrilas JP. AGA technical review on the clinical use of esophageal manometry. Gastroenterology 2005;128:209-24. 


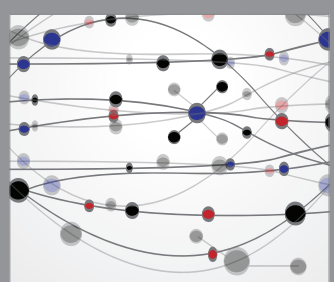

The Scientific World Journal
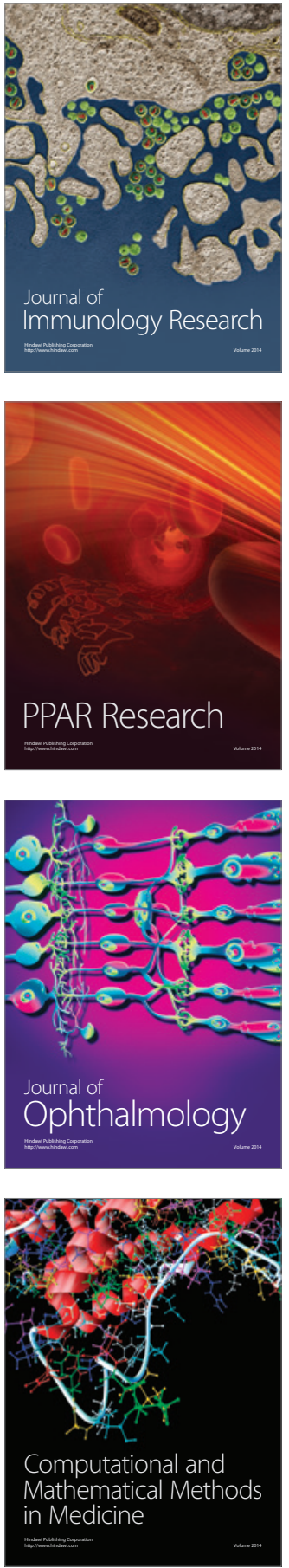

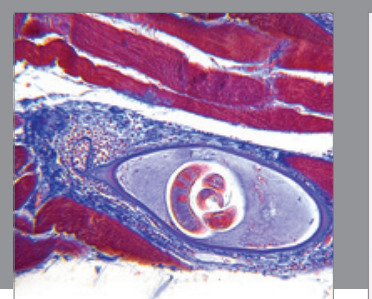

Gastroenterology Research and Practice

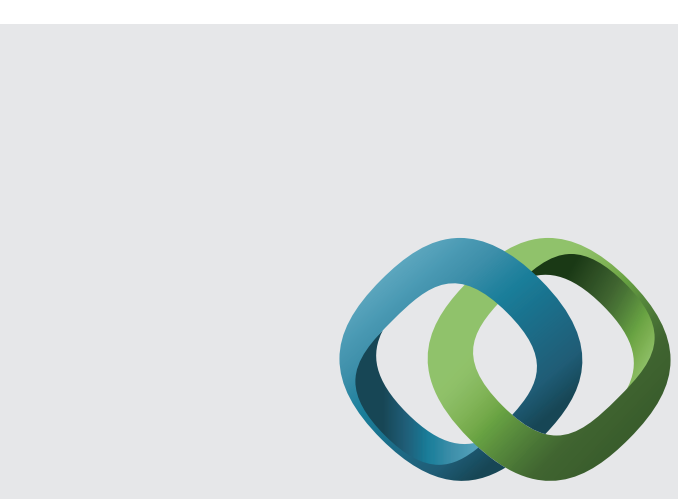

\section{Hindawi}

Submit your manuscripts at

http://www.hindawi.com
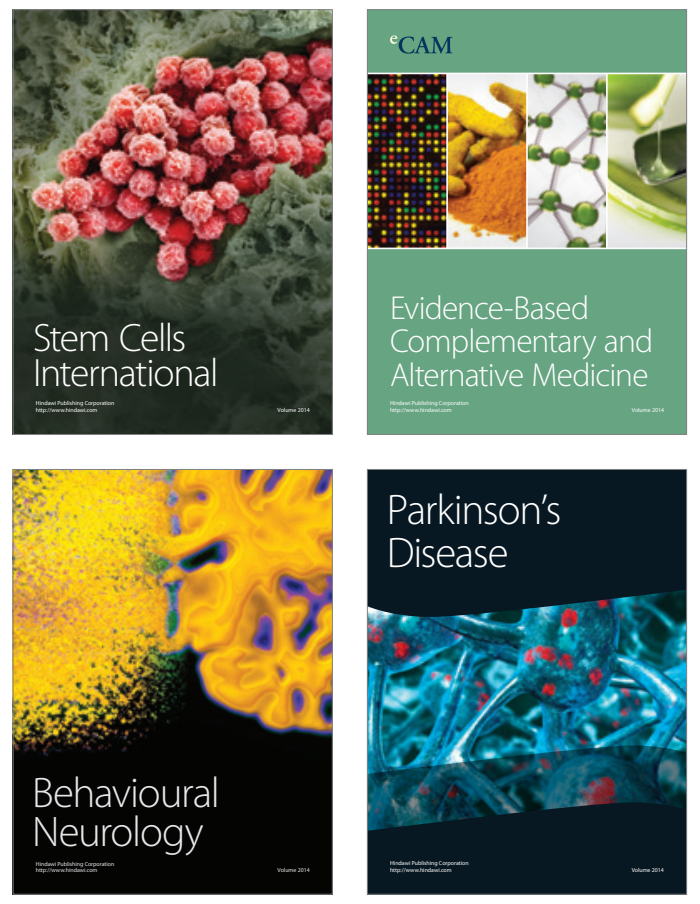
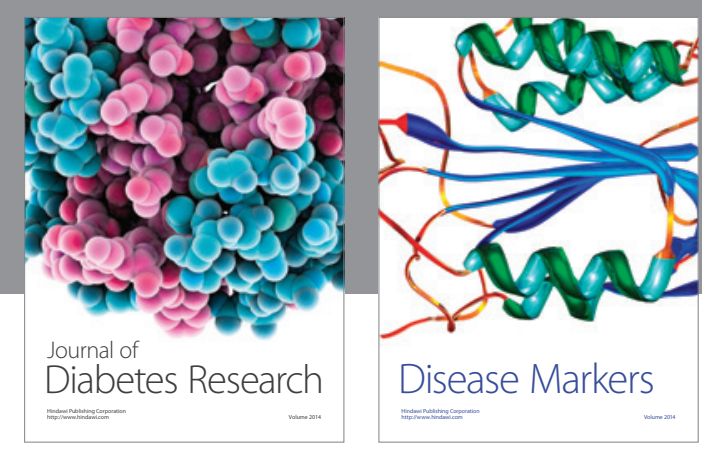

Disease Markers
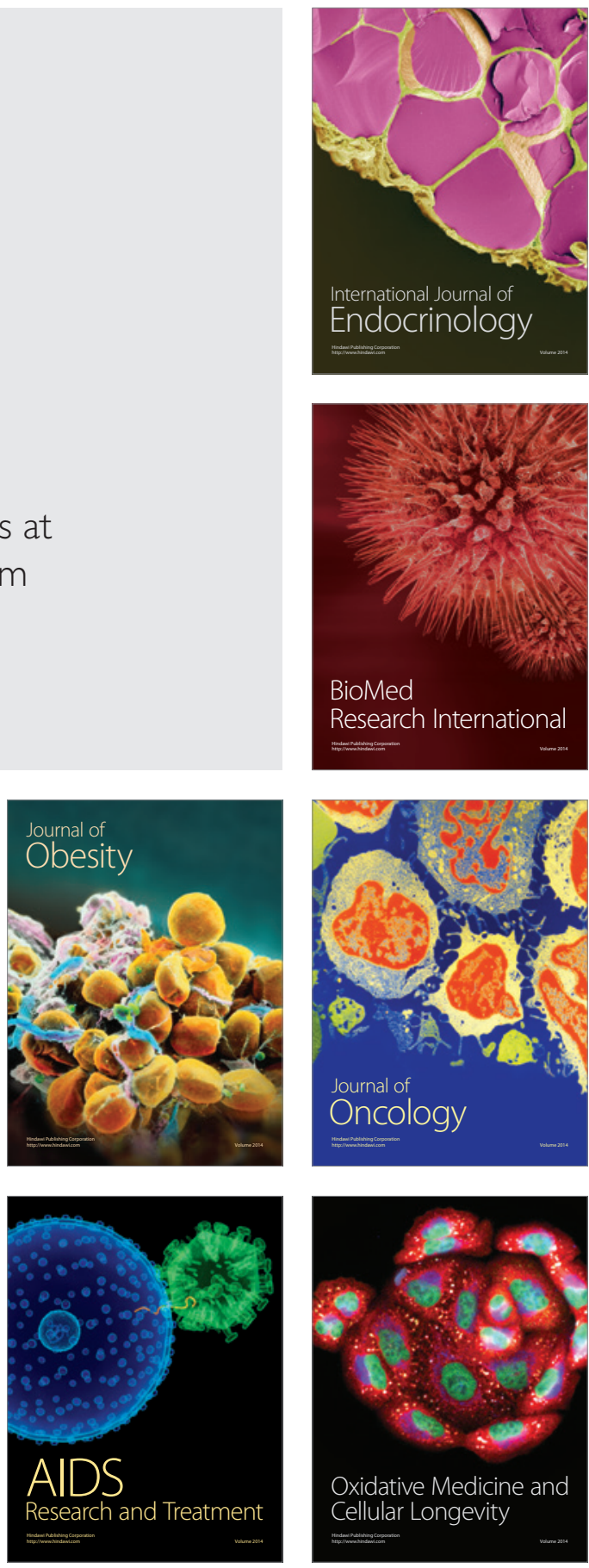